\title{
Video Article \\ Cryopreserving and Recovering of Human iPS Cells using Complete KnockOut Serum Replacement Feeder-Free Medium
}

\author{
Kate Wagner ${ }^{1}$, David Welch ${ }^{1}$ \\ ${ }^{1}$ GIBCO, Life Technologies
}

URL: https://www.jove.com/video/2237

DOI: doi:10.3791/2237

Keywords: Cellular Biology, Issue 41, iPS, pluripotent, stem cells, cell culture, medium, media, feeder-free

Date Published: $7 / 15 / 2010$

Citation: Wagner, K., Welch, D. Cryopreserving and Recovering of Human iPS Cells using Complete KnockOut Serum Replacement Feeder-Free Medium. J. Vis. Exp. (41), e2237, doi:10.3791/2237 (2010).

\section{Abstract}

The discovery in 2006 that human and mouse fibroblasts could be reprogrammed to generate iPS cells ${ }^{1-3}$ with qualities remarkably similar to embryonic stem cells has created a valuable new source of pluripotent cells for drug discovery, cell therapy, and basic research.

GIBCO media and reagents have been at the forefront of pluripotent stem cell research for years. Knockout DMEM supplemented with Knockout Serum Replacement is the media of choice for embryonic stem cell growth and now iPS cell culture ${ }^{3-9}$. This gold standard media system can now be used for feeder-free culture with the addition of Knockout SR Growth Factor Cocktail.

Traditional human ES and iPS cell culture methods require the use of mouse or human fibroblast feeder layers, or feeder-conditioned medium. These culture methods are labor-intensive, hard to scale and it is difficult to maintain hiPS cells undifferentiated due to the undefined conditions. Invitrogen has developed Knockout SR Growth Factor Cocktail to allow you to easily transition your hiPS and hES cell cultures to feeder-free while still maintaining your use of Knockout SR.

\section{Video Link}

The video component of this article can be found at https://www.jove.com/video/2237/

\section{Protocol}

Note: To maintain sterile culture conditions, all of the procedures in this protocol are carried out using sterile laboratory practices and conducted under a laminar flow hood.

Prior to starting, ensure that any media is equilibrated to $37^{\circ} \mathrm{C}$ and appropriately gassed.

\section{Preparing Geltrex-coated Culture Dishes}

Note: see appendix for the use of CELLstart coated culture dishes.

1. Thaw one tube of Geltrex $(1 \mathrm{~mL})$ slowly at $2-8^{\circ} \mathrm{C}$ and dilute $1: 100$ it in $99 \mathrm{~mL}$ of Knockout D-MEM/F-12. Mix the solution gently. Note: Some iPS cell lines may require a different Geltrex dilution for optimal growth. See appendix for alternative dilutions.

2. Cover the whole surface of each culture dish with the Geltrex solution ( $1 \mathrm{~mL}$ for a $35-\mathrm{mm}$ dish, $1.5 \mathrm{~mL}$ for a $60-\mathrm{mm}$ dish).

3. Seal each dish with Parafilm to prevent drying and incubate the dishes for 1 hour at $37^{\circ} \mathrm{C}$.

Note: At this point you may store the Geltrex-coated culture dishes at $4^{\circ} \mathrm{C}$ for up to 1 month. Seal each dish with Parafilm to prevent the Geltrex from drying out.

4. Prior to using, transfer the Geltrex-coated dishes to a laminar flow hood and allow them to equilibrate to room temperature (about 1 hour).

\section{Preparing Complete KnockOut SR Feeder-Free Medium}

1. To prepare $1 \mathrm{~mL}$ of $10 \mu \mathrm{g} / \mathrm{mL}$ Basic FGF solution, aseptically mix the components listed below. Aliquot the solution and store at $-20^{\circ} \mathrm{C}$ for up to 6 months.

\begin{tabular}{|l|l|}
\hline Basic FGF & $10 \mu \mathrm{g}$ \\
\hline D-PBS & $990 \mu \mathrm{L}$ \\
\hline $10 \%$ BSA & $10 \mu \mathrm{L}$ \\
\hline
\end{tabular}

Note: BSA can be substituted with HSA or Knockout SR at the same concentration.

2. To prepare $50 \mathrm{~mL}$ of $2 \mathrm{mg} / \mathrm{mL}$ Dispase solution, aseptically mix the components listed below. Filter sterilize the solution and store at $4^{\circ} \mathrm{C}$ for up to 2 weeks. 


\begin{tabular}{|l|l|}
\hline Dispase & $100 \mathrm{mg}$ \\
\hline D-PBS & $50 \mathrm{~mL}$ \\
\hline
\end{tabular}

3. To prepare $100 \mathrm{~mL}$ of complete KnockOut SR Feeder-Free (KSR-FF) aseptically combine the components listed in the table below.

\begin{tabular}{|l|l|l|c|}
\hline Component & Stock Concentration & Final Concentration & Volume \\
\hline $\begin{array}{l}\text { Knockout DMEM/F12 (Cat. } \\
\text { no. 12660-012) }\end{array}$ & - & $1 \mathrm{X}$ & $76.8 \mathrm{~mL}$ \\
\hline $\begin{array}{l}\text { GlutaMAX -I (Cat. No. } \\
\text { 35050-061) }\end{array}$ & $200 \mathrm{mM}$ & $2 \mathrm{mM}$ & $1 \mathrm{~mL}$ \\
\hline $\begin{array}{l}\text { KnockOut SR (Cat. no. } \\
\text { 10828-028) }\end{array}$ & - & $20 \%$ & $20 \mathrm{~mL}$ \\
\hline $\begin{array}{l}\text { KnockOut SR-GFC (Cat. } \\
\text { no. A10580-01) }\end{array}$ & $50 \mathrm{X}$ & $1 \mathrm{X}$ & $2 \mathrm{~mL}$ \\
\hline bFGF (Cat. no. PHG0024). & $10 \mu \mathrm{m} / \mathrm{mL}$ & $20 \mathrm{ng} / \mathrm{mL}$ & $200 \mu \mathrm{L}$ \\
\hline
\end{tabular}

You may store the KSR-FF medium at $2-8^{\circ} \mathrm{C}$ for up to one week.

4. Just before pre-equilibrating the complete medium to temperature and gases, aseptically add the required volume of 2 mercaptoethanol ( $55 \mathrm{mM}$ stock concentration) for a $0.1 \mathrm{mM}$ final concentration. For example, to prepare $100 \mathrm{~mL}$ of KSR-FF medium add $182 \mu \mathrm{L}$ of $55 \mathrm{mM} 2-$ mercaptoethanol (1:550 dilution) Alternatively, the 2-mercaptoethanol may be added to the $1 \mathrm{X}$ completed medium and stored at $2-8^{\circ} \mathrm{C}$ for up to one week.

\section{Preparing Freezing / Cryopreservation Medium}

The cryopreservation medium consists of two media; Freezing Medium A and Freezing Medium B. They are added to the cells at different times and must remain separated. They are each $50 \%$ of the total volume of Cryopreservation Medium needed. The total volume of Cryopreservation Medium needed is $1 \mathrm{~mL}$ for each vial to be frozen. A $90 \%$ confluent $60 \mathrm{~mm}$ dish of hESC can be used to bank 2 vials of hESC in cryopreservation media.

Prepare enough volume of each Freezing Medium with an extra $2-5 \mathrm{~mL}$ to ensure overage.

\begin{tabular}{|l|l|l|}
\hline Freezing Medium A (50\% of final volume): & $50 \%$ DMEM/F12 & $50 \%$ KSR \\
\hline Freezing Medium B (50\% of final volume): & $80 \%$ DMEM/F12 & $20 \%$ DMSO \\
\hline
\end{tabular}

\section{Example:}

If you are freezing 20 vials of cells, you will need $20 \mathrm{~mL}$ of Cryopreservation Medium. Add $4 \mathrm{~mL}$ for overage for a total of $24 \mathrm{~mL}$ Cryopreservation Medium. That means you will need $12 \mathrm{~mL}$ of Freezing Medium A ( $50 \%$ of $24 \mathrm{~mL})$ and $12 \mathrm{~mL}$ of Freezing Medium B $(50 \%$ of $24 \mathrm{~mL})$.

\begin{tabular}{|l|l|l|}
\hline Freezing Medium A (12 mL): & $6 \mathrm{~mL}$ DMEM/F12 & $6 \mathrm{~mL}$ KSR \\
\hline Freezing Medium B $(12 \mathrm{~mL}):$ & $9.6 \mathrm{~mL}$ DMEM/F12 & $2.4 \mathrm{~mL}$ DMSO \\
\hline
\end{tabular}

The final composition of the Cryopreservation Medium is $65 \% \mathrm{DMEM} / \mathrm{F} 12,25 \% \mathrm{KSR}$, and $10 \% \mathrm{DMSO}$.

\section{Cryopreserving iPSCs}

1. Pre-warm the required volume of Dispase in a $37^{\circ} \mathrm{C}$ water bath. Refer to Table 1 below for details on the volumes required.

2. Pre-equilibrate the required volume of $\mathrm{KSR}-\mathrm{FF}$ in a $37^{\circ} \mathrm{C}$ water bath for $15 \mathrm{~min}$. Refer to Table 1 below for details on the volumes required.

3. Aspirate the spent medium from the culture vessel using a pipette, and rinse the cells twice with D-PBS.

4. Gently add pre-warmed Dispase solution to the culture vessel (e.g., $1 \mathrm{~mL}$ of Dispase solution per 60-mm culture dish). Swirl the culture vessel to coat the entire cell surface.

5. Incubate the culture vessel at $37^{\circ} \mathrm{C}$ for 3 minutes.

6. Remove the vessel from the incubator, aspirate the Dispase solution, and gently wash the cells with D-PBS.

7. Gently scrape the cells off the surface of the culture dish using a cell scraper, and transfer the cells to a sterile $15 \mathrm{~mL}$ centrifuge tube.

8. Rinse the culture dish twice with KSR-FF, gently "spraying off" any cells that have not detached. Pool the rinse medium with the cells in the $15 \mathrm{~mL}$ tube.

9. Centrifuge the tube at $200 \times \mathrm{g}$ for 5 minutes at room temperature to pellet the cells.

10. Carefully aspirate the supernatant without disturbing the cell pellet and discard it.

11. Prepare a sufficient quantity of cryovials. Once the cells are in contact with DMSO, they should be aliquoted and frozen within $2-3$ minutes.

12. Gently flick the tube, to fully dislodge the cell pellet from the tube bottom and re-suspend the cells in Freezing Medium A. [by gently pipetting up and down using a 5-mL serological pipette]. Following uniform suspension of clumps, add equal volume of Freezing Medium $B$ to it, in a drop wise manner, while gently swirling the cell suspension to mix.

Note: At this point, cells are in contact with DMSO, and work must be performed efficiently. Once cells are in contact with DMSO, they should be aliquoted and frozen within 2-3 minutes.

13. Aliquot $1 \mathrm{ml}$ of the cell suspension into each cryovial.

14. Quickly place the vials in a Mr. Frosty [to rapidly freeze] and transfer it to $-80^{\circ} \mathrm{C}$ overnight. 
15. After overnight storage at $-80^{\circ} \mathrm{C}$, transfer the cells to a liquid nitrogen tank for long term storage.

\section{iPSC vial thaw and cell recovery}

Note: KSR-FF may be replaced with KSR-containing MEF-conditioned medium, or KSR medium for use with feeders. See appendix for instructions for media preparation.

Pre-warm $10 \mathrm{~mL}$ of KSR-FF medium in a $50 \mathrm{~mL}$ tube.

1. Equilibrate the appropriate quantity of Geltrex-coated dishes to room temperature and aspirate any liquid from the dishes just before plating your cells.

2. Carefully remove the hESC (or iPSC) vial from Liquid Nitrogen Storage Tank.

3. Rapidly thaw frozen vial of cells in a $37^{\circ} \mathrm{C}$ water bath, until just a small frozen chunk remains in the vial.

4. Spray vial with $70 \%$ isopropanol to decontaminate it and transfer it to the sterile tissue culture hood.

5. Aseptically transfer the entire contents of the vial into a $15 \mathrm{~mL}$ conical tube using a $5 \mathrm{~mL}$ pipette.

6. Rinse the vial with $1 \mathrm{~mL}$ of $\mathrm{KSR}-\mathrm{FF}$ and add this to the $15 \mathrm{~mL}$ centrifuge tube.

7. Slowly, add $4 \mathrm{~mL}$ of KSR-FF drop-wise to cells in the $15 \mathrm{~mL}$ conical tube. While adding the medium, gently move the tube back and forth to mix the cells. (This reduces osmotic shock to the cells).

8. Centrifuge the $15 \mathrm{~mL}$ tube with the cell suspension at $1000 \mathrm{rpm}(200 \times \mathrm{g})$ for 2 minutes at room temperature.

9. Carefully aspirate and discard the supernatant without disturbing the cell pellet.

10. Re-suspend the cell pellet in pre-warmed KSR-FF (e.g. $4 \mathrm{~mL} / 60 \mathrm{~mm}$ dish) using a $5 \mathrm{~mL}$ pipette and gently pipette the cells up and down until cell pellet is fully dispersed. A viability of greater than $70 \%$ is expected, however if the viability is less than $70 \%$, it may take longer for the cells to reach confluence.

11. Using the same pipette, transfer the cell suspension drop-wise to Geltrex-coated culture dish pre-equilibrated to room temperature.

12. Place the culture dish in a $37^{\circ} \mathrm{C}$ incubator, with a humidified atmosphere of 4 to $6 \% \mathrm{CO}_{2}$ in air. Carefully swirl vessel in a north to south, east to west pattern to evenly distribute the cells.

13. Gently fluid-change the culture dish $24 \mathrm{hrs}$ post-thaw and daily thereafter to remove cell debris and to provide fresh nutrients until the dish is approximately $70-80 \%$ confluent. For continued culture and passaging of your iPS cells, refer to our protocol titled "Feeder-Free Culture and Passaging of Human iPS Cells using Complete KnockOut Serum Replacement Feeder-Free Medium"

\section{Expected Results}

The cells should be roughly $70-80 \%$ confluent prior to cryopreservation. Dispase digestion results in curling up and folding of the colonies along the colony margins. After harvesting the cells they are frozen as small clumps in cryopreservation media. Once the vial is thawed, cells recover and attach to the pre-coated dish as small clumps. They grow rapidly leading to a confluent dish in 5-6 days.

\section{Table 1 - Recommended Volumes}

\begin{tabular}{|l|l|l|l|}
\hline Component & $\mathbf{3 5 m m}$ Dish & $\mathbf{6 0 m m}$ Dish & 100mm Dish \\
\hline Complete KnockOut SR medium & $2 \mathrm{~mL}$ & $4 \mathrm{~mL}$ & $10 \mathrm{~mL}$ \\
\hline Geltrex Solution & $1 \mathrm{~mL}$ & $1.5 \mathrm{~mL}$ & $4-5 \mathrm{~mL}$ \\
\hline Dispase & $0.5 \mathrm{~mL}$ & $1 \mathrm{~mL}$ & $3-4 \mathrm{~mL}$ \\
\hline D-PBS for rinsing & $2 \mathrm{~mL}$ & $4 \mathrm{~mL}$ & $10 \mathrm{~mL}$ \\
\hline
\end{tabular}

Please click here to see the appendix.

\section{Disclosures}

The authors of this article are employed by Life Technologies that produces reagents and instruments used in this article.

\section{References}

1. Takahashi, K. et al. Induction of pluripotent stem cells from mouse embryonic and adult fibroblast cultures by defined factors. Cell 126 , 663-676 (2006).

2. Takahashi, K. et al. Induction of pluripotent stem cells from adult human fibroblasts by defined factors. Cell 131, 861-872 (2007)

3. Yu, J. et al. Induced pluripotent stem cell lines derived from human somatic cells. Science 318, 1917-1920 (2007).

4. Maherali, N. et al. Guidelines and techniques for the generation of induced pluripotent stem cells. Cell Stem Cell 3, 595-605 (2008).

5. Li, W. et al. Generation of rat and human induced pluripotent stem cells by combining genetic reprogramming and chemical inhibitors. Cell Stem Cell 4, 16-19 (2009).

6. Liao, J. et al. (2009) Generation of induced pluripotent stem cell lines from adult rat cells. Cell Stem Cell 4, 11-15.

7. Dimos, J.T. et al. Induced pluripotent stem cells generated from patients with ALS can be differentiated into motor neurons. Science 321 , 1218-1221 (2008).

8. Aasen, T. et al. Efficient and rapid generation of induced pluripotent stem cells from human keratinocytes. Nat Biotechnli 26, 1276-1284 (2008). 
9. Park, I.H. et al. Generation of human-induced pluripotent stem cells. Nat Protoc 3, 1180-1186 (2008). 